\title{
PERIOPERATIVE COMMUNICATION FROM THE PERSPECTIVE OF PATIENTS UNDERGOING BARIATRIC SURGERY
}

\author{
Caroline Lemes Pozza Morales ${ }^{1}$, Jenefer Garcez Alexandre², Suzana Prim³, Lúcia Nazareth Amante
}

\footnotetext{
${ }^{1}$ RN. Master's student, Nursing Graduate Program, Federal University of Santa Catarina, Santa Catarina, Brazil. Email: carolpozz@gmail.com.

${ }^{2}$ RN. Tutor, Specialization in Family Health, Federal University of Santa Catarina, Santa Catarina, Brazil. Email: jenefergarcez@ hotmail.com.

${ }^{3}$ RN. Municipal government of Antônio Carlos, Santa Catarina, Brazil. Email: suzana_tuty@hotmail.com.

${ }^{4}$ Ph.D in Nursing. Assistant Professor, Department of Nursing, Federal University of Santa Catarina, Santa Catarina, Brazil. Email: luciamante@gmail.com.
}

\begin{abstract}
This was a qualitative and descriptive study that aimed to determine how patients understand instructions provided by a multidisciplinary team during perioperative periods of bariatric surgery. Data were collected through three individual interviews. Six patients admitted to a surgical unit of a university hospital in southern Brazil, in April and May 2012, participated in the study. Thematic analysis revealed three categories: communication in the perioperative period of bariatric surgery; quality of life and postsurgical care following bariatric surgery; and communication in the work process of the multidisciplinary team. The results showed satisfaction with the information received, but problems in the communication process and apprehension about life after surgery were highlighted. Furthermore, the absence of outpatient nursing care was demonstrated.
\end{abstract}

KEYWORDS: Morbid obesity, bariatric surgery, health communication, perioperative nursing.

\section{A COMUNICAÇÃO NO PERÍODO PERIOPERATÓRIO SOB A ÓTICA DOS PACIENTES SUBMETIDOS À CIRURGIA BARIÁTRICA}

RESUMO: Pesquisa qualitativa e descritiva, cujo objetivo foi verificar como o paciente compreende as orientações realizadas pela equipe multiprofissional durante o seu período perioperatório de cirurgia bariátrica. Os dados foram coletados por meio de três entrevistas individuais. Participaram seis pacientes internados em uma unidade cirúrgica de um Hospital Universitário do Sul do Brasil, em abril e maio de 2012. A análise temática evidenciou três categorias: A comunicação no período perioperatório de cirurgia bariátrica; Qualidade de vida e cuidados pós-cirúrgicos de cirurgia bariátrica e comunicação no processo de trabalho da equipe multiprofissional. Os resultados mostraram satisfação com as informações recebidas, porém foram apontados problemas no processo comunicacional, uma apreensão acerca de como será a vida após a cirurgia e evidenciado a ausência do acompanhamento ambulatorial da enfermeira. PALAVRAS CHAVE: Obesidade mórbida. Cirurgia bariátrica. Comunicação em saúde. Enfermagem perioperatória.

\section{COMUNICACIÓN EN EL PERIODO PERIOPERATORIO DESDE LA PERSPECTIVA DE LOS PACIENTES SOMETIDOS A CIRUGÍA BARIÁTRICA}

\begin{abstract}
RESUMEN: Investigación cualitativa y descriptiva, con objetivo de verificar como el paciente comprende las orientaciones realizadas por el equipo multiprofesional durante el período perioperatorio de la cirugía bariátrica. Los datos fueron recolectados a través de entrevistas individuales. Participaron seis pacientes admitidos en una Unidad de Internamiento Quirúrgica de un Hospital Universitario al Sur de Brasil, entre abril y mayo de 2012; todos firmaron el Instrumento de Consentimiento Libre e Informado. El análisis temático reveló la existencia de tres categorías: La Comunicación en el Periodo Perioperatorio de la Cirugía Bariátrica; Calidad de vida y Cuidado Postoperatorio en la Cirugía Bariátrica; y Comunicación en el Trabajo del Equipo Multidisciplinario. Los resultados mostraron satisfacción con la información recibida, sin embargo señalaron problemas en el proceso de comunicación, una aprensión relacionado con el cómo sería la vida después de la cirugía y demostraron la ausencia de la enfermera ambulatoria.
\end{abstract}

PALABRAS CLAVE: Obesidad mórbida. Cirugía bariátrica. Comunicación en salud. Enfermería perioperatoria 


\section{INTRODUCTION}

All surgical procedures require interaction between the health care team and patients and their families, to promote health through education about the various stages, procedures and results of surgery. From the preoperative period until hospital discharge, guidance and care are performed using human skills including communication. ${ }^{1}$ Obesity is a chronic disease characterized by the excessive accumulation of adipose tissue in the body, being listed by the World Health Organization (WHO) as the 5th leading cause of death in the world. With the exponential growth of obesity, the number of patients undergoing bariatric surgery has increased in recent years. ${ }^{2}$

According to the Brazilian Society of Endocrinology and Metabolism (SBEM) and the Brazilian Society of Internal Medicine (SBCM), the etiology of obesity is complex and multifactorial, and its treatment needs various types of approaches such as dietary counseling, physical activity scheduling, the use of anti-obesity drugs, and when a more effective intervention in the clinical management of severely obese patients is needed, bariatric operations. Bariatric surgery reduces the stomach capacity or alters gastrointestinal transit in order to reduce the signs of hunger and increase satiety signals, producing a controllable state of malnutrition. ${ }^{3}$

Patients are candidates for surgical treatment when their body mass index (BMI) is greater than $40 \mathrm{~kg} / \mathrm{m}^{2}$, or greater than $35 \mathrm{~kg} / \mathrm{m}^{2}$ when associated with: sleep apnea, type 2 diabetes mellitus, hypertension, dyslipidemia, locomotion problems, and others that are difficult to clinically manage. Patient selection requires a minimum of five years evolution of obesity with failure of conventional treatment methods carried out by qualified professionals. Surgery is not recommended for patients with severe lung disease, renal insufficiency, severe myocardial damage, and cirrhosis. Some authors cite psychiatric contraindications, which are still a source of controversy and a subject of debate. Furthermore, a BMI greater than $35 \mathrm{~kg} / \mathrm{m}^{2}$, pregnancy, chronic diseases unrelated to obesity, Prader-Willi syndrome, alcoholism and drug addiction are also contraindicate for bariatric surgery. ${ }^{3}$

The control of obesity may be accomplished by three types of surgical procedures: restrictive only; mixed (restrictive and malabsorptive) and purely malabsorptive (no longer used as bariatric surgery). ${ }^{3}$ Among the different surgical techniques, the Roux-En-Y Gastric Bypass or FobbiCapella surgery is considered the gold standard, and is currently the most frequently performed due to significant results: long-term weight loss with less recidivism of obesity, as well as acceptable levels of morbimortality. ${ }^{3}$

Obesity surgery is a therapeutic tool for sustained weight reduction and improvement of diseases associated with morbid obesity, but adherence to treatment by patients and their families is critical to its safety and good results. ${ }^{4}$ This procedure improves quality of life and self-esteem, but the life changes that occur and possible complications should be reported while the patients are candidates for surgery, so that they are aware of the processes that they will undergo, and their role as active agents in their treatment.

In this sense, patients undergoing this type of surgery should receive support and monitoring from an interdisciplinary team. The entire team should speak the same language as the patient. Each professional of this team is responsible for a part of the treatment, making the care more intensive and the results more rapid. ${ }^{2-3}$ Communication in the surgical process of bariatric surgery is one of the tools through which it is sought to make the patient and family feel safe, and motivated to modify habits and face the changes resulting from the surgical process, which in this case will be for the rest of the patient's life. ${ }^{4}$ However, there is a lack of studies focused on the communication process which is essential for both the patient and members of the professional multidisciplinary team. Health care professionals must make sure that patients understand and adhere to the treatment in the perioperative and late postoperative periods, and the patients need to understand the directions being provided so that they understand and are willing to adhere to the new condition resulting from bariatric surgery.

Thus, our goal was to determine how patients understand the instructions given by the professionals of the multidisciplinary team during their perioperative period of bariatric surgery. 


\section{METHOD}

This was a qualitative ${ }^{5-6}$ and descriptive study conducted in April and May 2012, through semi-structured individual interviews which were recorded in order to ensure the reliability of the data collected. Six patients who were hospitalized in a surgical unit of a university hospital in southern Brazil were interviewed and identified as PAT 1, PAT 2, PAT 3, PAT 4, PAT 5 and PAT 6. Inclusion criteria were: being at least 24 hours in preoperative bariatric surgery, over 18 years old, of either sex, with the ability to communicate, and would not be required to spend the postoperative period in the intensive care unit. The interviews took place in the shift change room of this surgical unit in three stages: in the first 24 hours of admission, at hospital discharge, and seven days after surgery, when the patients returned to the hospital for tube removal and to receive nutritional guidance. Among the six patients, five were female and one male. Their ages ranged from 28 to 48 years. Their Body Mass Index (BMI) ranged from 39.09 to $47 \mathrm{~kg} / \mathrm{m}^{2}$. The study was approved by the Ethics Committee on Human Research of the institution (Protocol 23.910). The thematic analysis, ${ }^{6}$ which enabled the development of three categories, was conducted in three stages: 1) Pre-analysis, in which documents were chosen and prepared through the initial reading of the text, and indicators were developed that represented the homogeneity and relevance of the categories; 2) Exploration of the material, which included phase coding of the data and transforming the data related to the objectives into values that comprise the table of results; 3) Treatment and interpretation of the results obtained: relevant information was grouped into units that allowed inferences and interpretations, and categorization of raw data formed a representation of the content.

\section{RESULTS AND DISCUSSION}

The categories resulting from the thematic analysis were: "Communication in the perioperative period of bariatric surgery"; Quality of life and post-surgical care after bariatric surgery"; and "Communication in the work process of the multidisciplinary team".

\section{Communication in the perioperative period} of bariatric surgery

Communication between health professionals, patients and families aims to identify and attend to the health needs of these people, contribute to the improvement of care, and promote faster and more efficient recovery. ${ }^{7}$ People about to undergo surgery have many fears that can alter their balance. Thus, explanation about the surgical procedure and recovery may reduce fears, insecurities and apprehensions, especially when professionals are available for dialogue..$^{8-9}$ It was noted that the patients received guidance in the preoperative period: I think I was well informed. They are always willing to respond to us, provide guidance (PAT 4); [...] [...] The nutritionist explained everything to me, drawing a picture and showing how the surgery would be done [...] she also told me about the dietary changes [...] she knew everything. She just didn't know about the anesthesia. I was pretty scared of the surgery center. That part was the hardest [...]. It was terrifying [...] I thought I would not get back to normal. It was the worst part. They also didn't talk about the drain that we would go home with it (PAT 1).

Although most patients affirmed having received information, PAT 1 cited a lack of information and that he felt fear and ignorance about what would happen. The lack of individualized guidance may cause the patients to have some doubts, since the information is provided in a very similar way to all, without taking into account their values, experiences and expectations. $^{10}$

The preoperative period is the proper time to establish interpersonal relationships with patients, and it is essential to have prior contact with them to explain about the procedures to be performed. Fear of anesthesia, lack of knowledge of preoperative preparation, the surgical procedure and recovery issues cause anxiety that can be avoided through embracement of clear and honest communication with patients and their families. ${ }^{8-9}$

The patients demonstrated knowledge about the procedures that should be performed in the preoperative period: perform medical exams, see the doctor, cardiologist, nutritionist, psychologist. Perform a blood test. Lose a little weight (PAT 2); 
[...] Diet, take a bath, wash the stomach with a green soap, fast and stay very calm [...], do not wash your hair and wear the clothes that they provide (PAT 3).

Patients were aware of what they should do in the preoperative period, revealing effective communication by the multidisciplinary team. The guidance for nutritional care should be initiated prior to bariatric surgery, to clarify the evolution of diet in the postoperative period. Orientation on dietary changes must be given according to the patient's timing, to avoid confusion and complications such as nausea, vomiting, dumping syndrome, diarrhea, constipation, gastric obstruction, food intolerance, insufficient weight loss, weight gain after the procedure, rupture of the staple line, and deficiency of some specific micronutrients, such as folic acid, iron and vitamin B12.11 That guidance on these issues was provided to the patients is proven by the following statements: I'll learn how to eat. Eat more fruit. I'll eat less, however, I am already eating. I have already lost 5 kilos. I started eating only liquids, now I can eat some baby food and mashed fruits. I thought it would be more difficult to get used to these dietary changes, but I'm managing. When I see someone eating something, of course I feel like eating, but I put it in my head that I can't and that's it (PAT 1); [...] For now I just have a little cup of coffee, juice or tea. I don't know what the next stage of the diet is. The nutritionist said that I should return on Wednesday, even though I don't have a drain to remove, to understand about the continuation of the diet. [...] I could get confused if she gives all the information now, because the change is really radical (PAT 6).

In order to ensure that the guidance is understood, the professionals use communication skills (spoken or written), particularly verbal communication. ${ }^{3-12}$ Patients receive numerous directions in the perioperative period of bariatric surgery, the majority of which are delivered orally, and thus important information is often forgotten or confused. To avoid such consequences, these directions should also be delivered in writing, as suggested by the patients: [...] Since I left sort of 'groggy', I didn't remember the directions correctly, so I would get the paper and read (PAT 3); [...] To receive something in writing would be good, because we always forget something, some detail. [...] An information sheet is good to take a look, to not get confused or forget information (PAT 4).
Communication involves interpersonal relationships, and sometimes problems, difficulties and restrictions can occur so that the message is not properly understood. Thus, when they relate to patients, health care professionals should try to speak slowly, focusing on the main ideas, repeating them and verifying that they were understood, because sometimes the patient has trouble grasping and understanding the information provided..$^{13}$ A lack in the communication process between the multidisciplinary health care team, or forgetfulness/difficulty in understanding by the patient, is observed in the following statements: How many days do I have to use heparin? (PAT 1 ); [...] The nutritionist didn't say anything to me, I'm unsure about the change in diet [...] (PAT 5); [...] Do I have to buy the heparin that I have to continue using? Do they give the prescription? (PAT 6).

Clarifying doubts allows the patient to understand certain situations and seek alternatives that minimize their anxiety. ${ }^{8}$ Perioperative care includes several procedures that may be initiated during consultation, including the various stages of hospitalization and return home. ${ }^{14}$ This care includes directions for hospital discharge made by the multi-professional team and/or by the nurse. In most cases, these directions are only made at the time of discharge from the hospital, and patients receive many directions at the same time, making it difficult for them to understand, and increasing the risk of forgetting and misunderstandings. ${ }^{15}$ This explanation would account for doubts, as shown by the comments above of PAT 1, PAT 5 and PAT 6.

Given that surgery for treatment of morbid obesity involves physical, psychological and nutritional aspects, among others, the patient should receive support and guidance from a multidisciplinary team. For this, the entire team should speak the same language with patients stressing that successful treatment depends not only on their commitment, but also on the absence of clinical, psychological and psychiatric complications, which can arise even after a long time has elapsed since the surgery. Thus, information and guidance to patients and their families should be offered from the moment the decision for surgery is made through the postoperative period, so that they understand the surgical process and know how to deal with the post-surgical changes. In the case of bariatric 
surgery, there are many changes that will last for the rest of the patients' lives. ${ }^{2-3}$

Although the patients reported that communication with the multidisciplinary team was satisfactory, communication failures still occurred. Thus, health care professionals need to reflect on the way that they communicate with patients and their families.

\section{Quality of life and post-surgical care of bariatric surgery}

Obesity is a problem that limits various aspects of life. It is a predisposing factor for many chronic diseases such as diabetes mellitus and cardiovascular disease, in addition to osteoarthritis, gastric reflux, respiratory disorders, sleep apnea and premature death. ${ }^{3}$ By involving multiple factors such as inadequate diets and psychological, genetic, demographic, social and environmental aspects, among others, many obese patients are not successful in reducing weight with nutritional guidance, physical exercise and antiobesity medications. ${ }^{3}$ Thus, bariatric surgery provides the patient with the opportunity to perform self-care, which is closely linked to quality of life and can be defined as the relationship between what is desired and what is achieved or achievable. Among obese people, there is a decrease in quality of life related to health, especially in physical capacity, psychological well-being and social functioning. ${ }^{15}$ Bariatric surgery benefits the obese patient because it can improve life expectancy, decrease mortality, and improve the pathologies associated with obesity, contributing to the general improvement of life for these patients. ${ }^{16}$

One of the concerns that frequently appeared in the statements of the interviewees was on life after bariatric surgery, highlighting care of the wound and drain, and post-surgery diet, which was the greatest concern that generated the most questions. The patients interviewed revealed hope for improved quality of life, health and self-esteem, as the following statements reveal: I hope for a new life, with better health, better quality of life (PAT 4); I hope that my health improves because now I feel an agony, the heavy body, I hope this gets better (PAT 5); everything better. Health, self-esteem [...] (PAT 2).

On the other hand, the objective of the patients undergoing bariatric surgery is not only to eliminate or alleviate diseases associated with obesity, but also to promote the improvement in the performance of daily activities, interpersonal affectivity and social life, as it allows for a return to social activities. ${ }^{17}$ Obese people also seek to fit into the current standards of beauty, as they suffer prejudice and discrimination due to their physical appearance. Finding clothes that fit well and proper sizes is also a challenge for these patients. ${ }^{16}$ The consolidation of bariatric surgery is a way to return to living and starting a new life, without feeling different from others, as shown in the following statement: new life: to be able to walk, dress better, exercise, eat better, dance again, in short, get back to living! [...] Before the clothes were horrible, many years ago I stopped doing a lot (PAT 3); it will be like a new phase of my life, a new beginning. I turned a page, hopefully I can turn this page and I'll write a new diary (PAT 6).

Other aspects, usually reasons for doubts on the part of bariatric patients, are related to postoperative care, especially with the wound and tubular drain. ${ }^{13}$ Thus, effort by the multidisciplinary team is essential to clarifying these questions, and interaction between the professionals and patients in preparation for surgery will lead to satisfactory recovery. ${ }^{1}$ Most of the patients demonstrated an understanding of the basic care of the surgical wound and the tube drain: $I$ am washing and drying it well. I'm not coughing in order to not rip any stitch. I am careful not to bump it (PAT 1); [...] To disinfect it well, clean it correctly, dry it well, apply the dressing, hold it when I cough, apply the injections [heparin]. [...] The drain can't be lifted much, or be pulled (PAT 3).

We can see that the multidisciplinary team provided useful guidance to the patients for care after hospital discharge, avoiding post-operative problems and promoting recovery. At this stage, work by the nursing staff makes the patient feel safe and motivated, enabling the recovery of their bio-psycho-socio-spiritual integrity. ${ }^{18}$ The patients were instructed in the hospital regarding the care of the surgical wound and drain after discharge, and some performed the care on their own. Others opted for help from a nursing professional: [...] I take off the dressing, when I take a shower I wash it well, and leave a soft cloth on top, because the nurses come to my home every day to put on the dressing. They wash it with serum, dry it well and apply the dressing (PAT 5); [...] I do the dressing 
with gauze every day, because I have children, and they don't touch it, to avoid contamination (PAT 2).

In PAT 2's statement, we see concern for infection of the wound, one of the most common complications that can occur both during hospitalization and after discharge. Clear guidance is needed on how to clean it, and appropriate use of aseptic technique during the dressing change.

Also related to self-care, diet is one aspect of the life of bariatric patients that will undergo the most changes. Nutritional treatment is started before the surgery and aims to promote initial weight loss, strengthen the patient's perception that it is possible to lose weight, identify eating disorders and errors, promote realistic expectations of weight loss, and especially prepare the patient for postoperative feeding. Moreover, only after a thorough nutritional assessment on dietary habits and the nutritional status of the patient is the recommendation for bariatric surgery assured. ${ }^{19}$

Diet in the postoperative period of bariatric surgery can vary according to the protocol of the bariatric team. It is generally agreed that the diet should allow gastrointestinal rest, aimed at proper healing and keeping the patient well hydrated. Food in the first 15 days of surgery should be liquid, and pasty/soft for the following 15 days. Solid foods will only be allowed in the second postoperative month, always under nutritional guidance, as this progression avoids complications such as vomiting and obstruction. ${ }^{13}$ The statements below show what the patients know about the postoperative diet: start with liquid diet for 15 days, I can drink tea, 'gatorade'. Then, the pasty/soft food for 15 days, too. And then normal food in small quantities, more salads (PAT 2); begin with liquids, then strained, then pasty. First comes a liquid amount in $\mathrm{ml}$ (not sure how much), then it increases (PAT 1).

We noticed that the respondents were provided with guidance about feeding after surgery with respect to the type of food and the time span of each stage; however, the amounts to be ingested were not remembered by any patient. Other directions were also mentioned, such as the consumption of fats, fizzy drinks and other foods that were part of patients' lives before surgery: I'm already doing it. I took out the fat, reduced it. I used to use five cans of oil, and today I use two to make lunch and dinner for the entire month. I switched to extra virgin olive oil. [...]. Fruits, I was not in the habit of eating fruit, but today I eat five fruits per day, five types of vegetables also (PAT 3). [...] I want to stop with soft drinks altogether and continue to eat fruits, salads and vegetables. I've always been a healthy chubby (PAT 4).

Analysis of the discourse of the bariatric patients regarding quality of life, wound care and feeding demonstrated a concern with self-care relating to basic needs. It can be inferred that the new lifestyle will cause an improvement in the lives of these patients, with a positive perception of themselves. On the other hand, the commitment to self-care revealed in the statements is a basic condition to achieve the improvement of their overall condition. In this sense, the communication established between the health care team and patients was positive.

\section{Communication in the work process of the multidisciplinary team}

Each patient should be understood as unique, with different needs which guide the health care work process. Thus, knowledge of the history of the patients (drug or food allergies, comorbidities associated with the underlying disease, smoking and alcohol consumption), and their social networks (family, friends, support groups), among others, are factors that make health care and the work process unique. The work process during the perioperative period requires organization of the care provided by members of the health care team, so that the surgical procedure is performed successfully and safely. ${ }^{20}$

The concern to provide effective and continuous care is evidenced by way of providing guidance to patients and families, through consultation with an interdisciplinary team, which is available to respond to questions, resolve doubts and provide reassurance to patients undergoing bariatric surgery and their families. The implementation of care makes the patients trust the team, bringing them satisfaction and peace through clarification of the type of surgery and the stages through which they will pass. The importance given by patients to the care provided can be seen in reports of satisfaction and improvement in care, as well as through the suggestions that emerged: [...] it was explained well throughout the pre-surgical process [...]. I think the hospital staff 
is being restructured. They are getting better [...]. I think the staff are well focused, well directed (PAT 6); [...] This way is fine. But I think that the psychologist could speak longer with us [...] a friend of mine decided not to do it because she was not prepared for the surgery (PAT 5).

The statements reflect the perceptions of the patients about the need to optimize the care service provided. This need is due to the awareness of surgical and post-surgical risks, so that the patients want to receive further information in different ways for better understanding of the surgical process. The lack of guidance and continuous monitoring can lead the patient to refuse to undergo the surgery, reflecting recognition of the changes which they will undergo without due preparation, or accept the surgery and suffer the consequences of a surgical procedure for which they were not properly prepared.

The nursing staff is directly involved in patient care, with the aim of reducing anxiety through multiple actions: preparing the environment and providing support; promoting proper nutrition; encouraging the patient to eat foods that reduce gastric irritation, and in small portions; monitoring fluid therapy and drug therapy; assessing pain; promoting relief and comfort; conducting orientations and assisting in presurgical preparation (in the bath, administering pre-anesthetic medication according to medical prescription); collaborating with the organization of medical records; delivering and accompanying the patient to the operating room; assisting and monitoring the onset of postoperative food intake, predicting and acting on possible complications; monitoring and preventing the onset of bleeding, thromboembolism, ulcers, metabolic imbalances, and surgical site infections, among others. ${ }^{13}$

This nursing care contributes to the prevention of complications in the perioperative period. ${ }^{1,13}$ Based on their general skills (health care, decision-making, leadership, etc.), the nurse delegates and supervises the specific activities of the nursing staff through work planning. ${ }^{21}$ Therefore, it is necessary to know the individual by completing the nursing history and establishing a trusting relationship. In the process of bariatric surgery and in the nursing consultations, nurses collect the data for the health history and physical examinations, and organize the nursing interventions to be performed throughout the perioperative period.

For better patient adherence to treatment, nurses share responsibility through guidance, sincerity and respect for the choices the patient makes. Nursing interventions to be performed in the perioperative period range from care of skin and the surgical wound, hygiene and comfort, drains, medications, exercises to mobilize members, as well as psychosocial health, attention to anxieties related to the surgical procedure, doubts regarding absenteeism from work and/or the family, and guidance about the importance of having a companion. ${ }^{13}$

Doubts are clarified during the nursing consultation, making the patient feel safe regarding the surgery. ${ }^{1}$ Of the six patients interviewed, five of them showed insecurity, fears and doubts when they were still in the preoperative period: They still haven't talked about this at all [...]. What scares me is the drain. For me it is a big deal (PAT 4); [...] They didn't tell me anything about the wound, or the dressing. There's the drain too. I do not know the care (PAT 5).

We observed that the lack of nursing consultation in the preoperative period can make the patient insecure and fearful about what may happen. Anxiety in the preoperative period may be a factor that hinders patients' understanding of the information provided. Thus, an outpatient nursing orientation would probably offer a more effective and individualized result. ${ }^{9}$ When the patients spoke about the professionals who performed the orientations, they did not mention the nurse, as we can see in the following: It was the nutritionist who provided me with the most information; the psychologist taught me to retrain my eating [...]. The physical therapist [...] taught me breathing; the endocrinologist guided me during consultations [...] (PAT 1). The endocrinologist, nutritionist, cardiologist, social worker, psychologist, physiotherapist, all of these from the beginning. Today I spoke with the doctor who ordered tests [...] (PAT 2).

It was observed that after the hospitalization period, the nurse is remembered by the patients: The surgeons, the nutritionist and the nursing staff are always asking if we need anything, if everything's okay (PAT 2); the psychologist, nutritionist, surgeon, nurses, pharmacists (PAT 3).

The presence of nurses as members of multidisciplinary teams is crucial, however, 
professional recognition still depends on nursing, because only those who are present are recognized. Thus, it is the nurse's responsibility to search for a practice in which all of the professionals on the multidisciplinary team collaborate on clinical decisions, making the work process decentralized, and everyone will share responsibility for the decisions, and be committed to the appropriate care.

\section{FINAL CONSIDERATIONS}

This study noted that the patients understand the guidelines provided and that commitment is essential to the therapy; however, weaknesses were identified in the communication process established between the multidisciplinary team and the patient/family, such as lack of information and the use of oral language only, in addition to the information for hospital discharge occurring just at the time of discharge from the hospital, and lack of outpatient nursing care during the pre-and postoperative periods.

This study may contribute to understanding what the therapeutic process involves besides the surgical procedure, such as sustaining of a way of living life through an effective communication process, and that the ability to understand the patient is fundamental to the success of bariatric surgery. Therefore, it is necessary that professionals rethink how they are communicating with patients and their families, and the presence of nurses is essential throughout the perioperative period, because this is when a relationship of trust is established with patients, and nurses can intervene, reinforcing actions for their safety. Regarding the forms of communication, in addition to the directions delivered orally, it is suggested that these are also delivered in writing and provided during the hospitalization and subsequent visits to the hospital, including by nurses during the nursing consultation. We believe that the advancement of nursing knowledge about obese people and bariatric surgery is based on effective communication.

\section{REFERENCES}

1. Christóforo BEB, Carvalho DS. Cuidados de enfermagem realizados ao paciente cirúrgico no período pré-operatório. Rev Esc Enferm USP. 2009 Mar; 43(1):14-22.
2. Costa LD, Valezi AC, Matsuo T, Dichi I, Dichi JB. Repercussão da perda de peso sobre parâmetros nutricionais e metabólicos de pacientes obesos graves após um ano de gastroplastia em Y-de-Roux. Rev Col Bras Cir. 2010 Mar-Abr; 37(2):96-101.

3. Petroianu A, Miranda ME, Oliveira RG. Blackbook cirurgia - Medicamentos e rotinas médicas. $1^{\mathrm{a}} \mathrm{ed}$. Belo Horizonte (MG): Blackbook editora; 2008.

4. Rockenbach KF. Cirurgia bariátrica: evolução nutricional no pós-operatório [trabalho de conclusão de curso]. Cascavel (PR): Curso de Nutrição, Faculdade Assis Gurgacz; 2006.

5. Cuesta Benjumea C. Pesquisa qualitativa e desenvolvimento do conhecimento em enfermagem. Texto Contexto Enferm. 2010 Out-Dez; 19(4):762-6.

6. Minayo MCS. O desafio do conhecimento: pesquisa qualitativa em saúde. $11^{\mathrm{a}}$ ed. São Paulo (SP): Hucitec, Abrasco; 2008.

7. Milbrath VM, Siqueira HCH, Motta MGC, Amestoy SC. Comunicação entre a equipe de saúde e a família da criança com asfixia perinatal grave. Texto Contexto Enferm. 2011 Out-Dez; 20(4):726-34.

8. Lima FB, Silva JLL, Gentile AC. A relevância da comunicação terapêutica na amenização do estresse de clientes em pré-operatório: cuidando através de orientações. Inf Prom Saúde. 2007; 3(2):17-18.

9. Razera APR, Braga EM. A importância da comunicação durante o período de recuperação pós-operatória. Rev Esc Enferm USP. 2011 Jun; 45(3):632-7.

10. Kruse MHL, Almeida MA, Keretzky KB, Rodrigues E, Silva SP, Schenini FS, et al. Orientação préoperatória da enfermeira: lembranças de pacientes. Rev Eletr Enf [Internet]. 2009 Jul-Set [acesso $2012 \mathrm{Fev}$ 22]; 11(3):494-500. Disponível em: http:/ / www.fen. ufg.br/revista/v11/n3/v11n3a05.htm

11. Martins JSS, Paganotto M. Hábitos de vida no pósoperatório de gastroplastia: correlação com peso. Cad Esc Saúde. 2010; 1(4):30-45.

12. Oriá MOB, Moraes LMP, Victor JF. A comunicação como instrumento do enfermeiro para o cuidado emocional do cliente hospitalizado. Rev Eletr Enf [online]. 2011 Abr-Jun [acesso 2011 Out 10]; 6(2):292-97. Disponível em: http://www.fen.ufg. br/fen_revista/revista6_2/pdf/R4_comunica.pdf

13. Morais GSN, Costa SFG, Fontes WD, Carneiro AD. Comunicação como instrumento básico no cuidar humanizado em enfermagem ao paciente hospitalizado. Acta Paul Enferm. 2009 Mai-Jun; 22(3):323-7.

14. Sociedade Brasileira de Cirurgia Bariátrica e Metabólica [homepage na internet]. Cirurgia Bariátrica e Metabólica: Equipe Multidisciplinar Enfermagem [acesso 2012 Mai 23]. Disponível em http://www.sbcb.org.br/coesa.asp?menu $=6$

15. Pompeo DA, Pinto MH, Cesarino CB, Araújo RRDF, Poletti NAA. Atuação do enfermeiro na alta 
hospitalar: reflexões a partir dos relatos de pacientes. Acta Paul Enferm. 2007 Jul-Set; 20(3):345-50.

16. Toledo CC, Guimarães RL, Camilo GB, Moraes FR. Qualidade de vida no pós-operatório tardio de pacientes submetidos à cirurgia bariátrica. Rev APS . 2010 Abr-Jun; 13(2):202-9.

17. Lemos MCM. Qualidade de vida de pacientes submetidos a cirurgia bariátrica no município de Cascavel/PR. Arq Ciênc Saúde Unipar. 2006 SetDez; 10(3):155-63.

18. Yokokura AVCP, Silva AAM, Araújo GF, Cardoso LO, Barros LCMM, Sousa SMA. Obesidade e cirurgia Bariátrica no olhar dos ex-obesos mórbidos. Saúde Debate. 2011 Jul-Set; 35(90):462-69.

19. Gritten L, Méier MJ, Gaievicz AP. Visita préoperatória de enfermagem: percepções dos enfermeiros de um hospital de ensino. Cogitare Enferm. 2006 Set-Dez; 11(3):245-51.

20. Marchesini SD. Acompanhamento psicológico tardio em pacientes submetidos à cirurgia bariátrica. ABCD Arq Bras Cir Dig. 2010 Jun; 23(2):108-13.

21. Peres AM, Ciampone MHT. Gerência e competências gerais do enfermeiro. Texto Contexto Enferm. 2006 Jul-Set; 15(3):492-9. 